\title{
Biurokracja a wzrost gospodarczy kraju
}

\section{Wstęp}

Według Nowej encyklopedii powszechnej PWN, „biurokracja jest to hierarchiczna, regulowana przepisami organizacja, oparta na określonym w kontrakcie stosunku bezpośredniej zależności służbowej między zwierzchnikiem i podwładnym, której personel przyjmuje stałe wynagrodzenie pieniężne". Termin biurokracja ${ }^{1}$ pojawił się w XVIII w. we Francji; w XIX w. stosowano go w odniesieniu do administracji państwowej.

Od wielu lat jedyny kontekst słów „biurokrata” i „biurokracja” był negatywny, stanowił nazwanie marnotrawstwa i niekompetencji urzędników, a same słowa brzmiały w potocznym znaczeniu nieco obelżywie.

Zauważa się to także w definicji podanej przez Kopalińskiego: „biurokracja, to ogół ludzi administrujących, zarządzających, organizujących pracę instytucji i ich urzędników; władza oderwana od mas, narzucająca im decyzje społecznie szkodliwe. Biurokratąjest urzędnik bezduszny; ślepo trzymający się formalnej strony przepisów" [Kopaliński 1968: 106].

W języku potocznym biurokracja oznacza niesprawne i nieskuteczne działanie administracji państw, nadmierną formalizację i opieszałość w załatwianiu spraw. Powszechne znaczenie biurokracji, pojmowanej jako dowolnie i bezdusznie funkcjonujący aparat urzędniczy, odbiega od weberowskiego typu idealnej biurokracji, przyjętego przez współczesny model państwa demokratycznego.

U Maxa Webera władza państwowa przypisuje sobie monopol przymusu, którym może dysponować w sposób legalny (prawny), a aparat tego przymusu jest wyspecjalizowany i zinstytucjonalizowany, wyposażony we własną legitymność (suwerenny) [Błaszczyk 1997: 18].

Aparat biurokratyczny uznał Weber za ważne centrum władzy. Reprezentuje on jej część wykonawcza, złożony jest z zawodowego personelu profesjonalistów, w przeciwieństwie do personelu politycznego, składającego się

${ }^{1}$ Od francuskiego bureau - biuro i greckiego kratos - władza. 
$\mathrm{z}$ mandatariuszy społeczeństwa, zmiennego w składzie, zależnego od ujawnionej w wyborach opcji politycznej społeczeństwa. Rosnące znaczenie weberowskiej biurokracji jest związane $\mathrm{z}$ rozwojem gospodarki, wymagającej nowoczesnego, profesjonalnego zarządzania w skali makroekonomicznej.

Według Ludwiga von Misesa prowadzenie rządowego aparatu przymusu i zniewolenia musi $z$ konieczności być formalistyczne i biurokratyczne. Żadna reforma nie potrafi usunąć znamion biurokracji z państwowych instytucji [Mises 1998].

Przedmiotem artykułu jest analiza ekonomiczna znaczenia struktur władzy biurokratycznej, zwłaszcza instytucji publicznych, w stymulowaniu bądź hamowaniu wzrostu gospodarczego. Wyjaśnienie, dlaczego niektóre biurokracje państwowe są bardziej efektywne niż inne jest wyzwaniem, wykraczającym poza zwykłą krytykę nadmiernej interwencji państwa w gospodarce. Jeśli jesteśmy rzeczywiście zainteresowani podnoszeniem przeciętnego poziomu życia ludności, to ważne jest zrozumienie procesu wzrostu gospodarczego w kraju.

\section{Biurokracja a wzrost gospodarczy - przegląd literatury}

Na początku XX wieku Weber dowodził, że biurokracja stanowi jedną $\mathrm{z}$ instytucjonalnych podstaw wzrostu gospodarki kapitalistycznej [Weber 1978], ale jego teza „biurokracji jako narzędzia wzrostu” była podważana przez historycznie wcześniejszy i ideologicznie silniejszy pogląd „laissez-faire” (,smithsowski"), według którego państwo, bèz względu na jego formę organizacyjna, jest zawsze wrogiem wzrostu gospodarczego, gdy tylko wychodzi poza funkcję ochrony praw własności. W latach 70. i 80. ubiegłego wieku neoklasyczna ekonomia polityczna $i$ analiza racjonalnego wyboru [Buchanan i in. 1980; Colclough, Manor 1991; Collander 1984; Krueger 1974] umocnity teoretycznie smithsowski punkt widzenia. $Z$ kolei badania nad zjawiskiem poszukiwania renty („rent seeking”) oraz zachłannością (łupieżczością) państwa, prowadzone m.in. przez Batesa [1981] oraz Klitgaarda [1988] przyniosły empiryczne uzasadnienie tych teorii.

W latach 90. ekonomiści skupili się na badaniach w przekroju międzynarodowym, które pokazały, jak duże znaczenie ma głębsze przyjrzenie się sposobowi organizacji państwa w kontekście jego oddziaływania na wzrost gospodarczy. Ich wyniki dowodziły, że różnoródne. mierniki jakości rządzenia są ściśle związane ze wzrostem gospodarczym [Mauro 1995; Knack, Keefer 1995; Rose-Ackerman 2001]. Coraz bogatsza literatura przedmiotu dawała do zrozumienia, że wcześniejsze neoklasyczne wyobrażenie funkcjonowania rządu było 
nazbyt uproszczone. We współczesnych badaniach empirycznych problemu jakości rządzenia, poszukiwania renty czy też korupcji termin „biurokracja” jest jednak używany raczej w sensie pejoratywnym, a nie wedhug ujęcia weberowskiego jako system organizacji administracji o swoistej strukturze. Weber nie patrzył na biurokrację jak na zbiór urzędników państwowych, lecz jak na szczególny rodzaj struktury organizacyjnej, utworzonej na zasadzie kontrastu do wcześniejszych patrymonialnych i prebendalnych form administracji rządowej. Należy zaznaczyć, że weberowski punkt widzenia nie neguje pozytywnych efektów umacniania instytucji rynkowych, sugeruje jednak, że biurokratycznie zbudowane organizacje publiczne, wykorzystując swoje specyficzne procedury decyzyjne, są niezbędnym uzupełnieniem tych instytucji. Weber był zdania, że organizacje administracji publicznej, które cechują się merytorycznym doborem pracowników oraz długookresową przewidywalnością ich kariery zawodowej są bardziej skuteczne w pobudzaniu wzrostu gospodarki kapitalistycznej niż inne formy organizacji państwa. Wydaje się, że do obalenia tej tezy nie wystarczą empiryczne odkrycia, że biurokraci dążą do poszukiwania renty lub że skorumpowane rządy destabilizują wzrost gospodarczy.

Dotychczasowa literatura na temat roli biurokracji w promowaniu lub hamowaniu wzrostu gospodarczego obejmuje szeroki zakres podmiotowy, począwszy od szczegółowej analizy przypadków określonych agencji rządowych w określonych krajach, a skończywszy na badaniach na poziomie wielonarodowym, opartych na szeregach czasowych danych statystycznych $\mathrm{z}$ wielu państw. Analizy przypadków prowadzone były na ogół przez naukowców z dziedziny nauk politycznych (np. Stepana [1978]; Waterbury'ego [1983]), natomiast badania na płaszczyźnie wielonarodowej głównie przez socjologów (np. Snydera i Kicka [1979] oraz Delacroix i Ragina [1981]).

Wśród ekonomistów studia nad wzrostem gospodarczym w przekroju międzynarodowym cieszą się ponownie żywym zainteresowaniem od pojawienia się teorii realnego cyklu koniunkturalnego, a zwłaszcza teorii endogenicznego wzrostu, które merytorycznie wsparły tezę o zasadniczym wpływie czynników instytucjonalnych na stopę wzrostu gospodarczego [Lucas 1988; Romer 1994, 1990].

Główny wpływ pierwszej fali nowej teorii klasycznej na analizę polityki polegał na dostarczeniu odpornego argumentu teoretycznego przeciwko aktywnej działalności państwa [patrz Kydland i Prescott 1977]. Również literatura na temat politycznego cyklu koniunkturalnego postawiła pod znakiem zapytania kwestię, czy można dać wiarę politykom, że posłużą się polityką stabilizacji w celu ograniczenia fluktuacji, a nie w celu maksymalizacji swoich własnych interesów [Nordhaus 1975].

Najwcześniejsze i najbardziej wpływowe badania empiryczne na grupie państw nad pozaekonomicznymi czynnikami wzrostu gospodarczego prowadził 
Barro [1991]. Położył w nich nacisk na negatywną rolę rządu (państwa) poprzez wykazanie ujemnego wpływu konsumpcji rządowej (mierzonej odsetkiem PKB) na stopy wzrostu gospodarczego.

W badaniach socjologicznych, a tym bardziej ekonomicznych, brakowało jednak takich, które w sposób poważny i kompleksowy zajęłyby się wpływem zmian w organizacji administracji państwa na dynamikę gospodarki.

Na początku lat 90. Bank Światowy opracował raport na temat gospodarek „tygrysów azjatyckich", w którym wskazał na pozytywną rolę odegraną przez wschodnioazjatyckie biurokracje w spektakularnej industrializacji regionu [World Bank 1993]. Raport ten powstał jednak jako kolejna analiza przypadku. W kolejnym raporcie, opierając się na analizie danych z 94 państw za 30-letni okres, argumentował, że to nie polityki ekonomiczne ani kapitał ludzki determinują wyniki makroekonomiczne, lecz jakość instytucji w państwie. Słabe instytucje powiększają samowolę agencji państwowych i urzędników publicznych [World Bank 1997].

Jednym z najbardziej znanych na świecie współczesnych ekonomistów (związanych też $z$ Bankiem Światowym), który od lat zajmuje się tematyką rozwoju gospodarczego, w tym związku między sprawnością administracyjną państwa a wzrostem gospodarczym jest Joseph E. Stiglitz [1991; 1996; 1998].

Jednak odpowiedzi na pytanie, czy w krajach, gdzie aparat administracyjny jest bardziej zbliżony do biurokratycznych form organizacji, występuje wyższa stopa wzrostu gospodarczego, dopiero pod koniec lat 90. zaczęli poszukiwać m.in. Evans i Rauch [1999]. Swoje badania oparli na danych pierwotnych, charakteryzujących główne agencje państwowe kreujące politykę gospodarczą oraz na miernikach wzrostu gospodarczego w 35 rozwijających się krajach w okresie 1970-1990. Opracowali "skale państwa weberowskiego" (Weberian State Scale), która jest miara stopnia, w jakim wspomniane agencje stosują merytoryczne kryterium naboru pracowników oraz oferują im satysfakcjonującą długookresową karierę zawodową.

Merytoryczna rekrutacja pracowników została wzięta pod uwagę nie tylko ze względu na to, że zwiększa prawdopodobieństwo posiadania przez urzędników co najmniej minimalnych kompetencji, ale również dlatego, że sprzyja spójności zespołu oraz esprit de corps, co z kolei może mieć wpływ na motywacje poszczególnych urzędników. Jest bardziej prawdopodobne, że biurokraci, którzy widza, że są włączeni do zespołu na mocy posiadania podobnych umiejętności, będą kierować się zbliżonymi wartościami i realizować wspólne cele niż ci, którzy zawdzięczają swoją pozycję krewnym bądź patronom i mają wobec nich swoisty dług wdzięczności. Identyfikowanie się z kolegami i organizacją minimalizuje także możliwości działań korupcyjnych, które mogą zagrażać celom organizacji, a ponadto zwiększa efektywność kontroli. Zagwa- 
rantowanie długoterminowej wieloszczeblowej kariery zawodowej tak samo może, wraz z upływem czasu, powiększać kompetencje poszczególnych urzędników, a niewątpliwie służy poprawie koordynacji zespołowego działania. Długofalowa perspektywa zachowania posady żmniejsza atrakcyjność doraźnych korzyści z korupcyjnych procederów. Wydaje się jednak, że na ogół jest to możliwe tylko wtedy, gdy urzędnicy mają jednocześnie zapewnione konkurencyjne wynagrodzenie. Innym aspektem stosowania zasady dhugoterminowej kariery jest wzrost skłonności biurokracji do popierania inwestycji w sektorze publicznym zamiast wydatków konsumpcyjnych. Z kolei ograniczenie praktyk korupcyjnych pomniejsza ,ukryte podatki” nakładane na sektor prywatny.

W literaturze naukowej ważkość rozległych powiązań biurokracji z gospodarką jest przedmiotem przede wszystkim analizy przypadków konkretnych krajów, zwłaszcza rozwijających się. Gros z niej [m.in. Johnson 1982; Amsden 1989; Wade 1990; World Bank 1993; Evans 1995] odnosi się do roli biurokracji państwowej w wywoływaniu wzrostu stopy inwestycji prywatnych. Oczywiste jest, że racjonalni, niechętni ryzyku przedsiębiorcy będą unikać długoterminowych inwestycji, jeśli mają do czynienia ze skorumpowaną, nieprzewidywalną biurokracją, która nie jest w stanie zapewnić komplementarnych inwestycji publicznych. Z drugiej strony, ogólna percepcja wiarygodnej, przewidywalnej i fachowej biurokracji, której zależy na wzroście gospodarczym powoduje, że inwestycje stają się w odczuciu przedsiębiorców mniej ryzykowne. Biurokracja może także sprawić, że źródła informacji staną się dobrem publicznym, co z kolei zwiększa szanse i efektywność inwestycji.

Wspomniani wcześniej Evans i Rauch przyjęli hipotezę, że kraje, w których struktury biurokratyczne mają cechy weberowskie osiaggnęły wyższe stopy wzrostu gospodarczego w okresie dwudziestu lat (między 1970 a 1990 rokiem). Badania doprowadziły ich do ważnego wniosku, że charakterystyki weberowskie mają silną zdolność predykcyjną w szacowaniu wzrostu gospodarczego, a ponadto $\mathrm{w}$ sposób zadowalający wyjaśniają regionalne zróżnicowanie stopy wzrostu gospodarczego między badanymi krajami ${ }^{2}$.

Implikacją uzyskanych wyników jest postulat uwzględnienia wskaźników weberowskich w modelach wzrostu gospodarczego oraz zwracania przez polityków większej uwagi na konieczność budowania lepszych biurokracji, natomiast przez naukowców - na pozaekonomiczne czynniki wzrostu gospodarki narodowej.

\footnotetext{
${ }^{2}$ Niezwykle szybki wzrost gospodarczy w nowo uprzemysłowionych krajach Azji Wschodniej oraz wyjątkowo niski w przypadku państw Afryki Subsaharyjskiej może być wyjaśniony na bazie regionanych różnic stopnia zbliżenia administracji tych państw do biurokracji weberowskiej.
} 


\section{Biurokracja weberowska a biurokracja polska}

W klasycznym modelu nowożytnej biurokracji sformułowanym przez Maxa Webera [1978] biurokracja działa opierając się na regułach prawnych i dokumentacji pisanej, urzędnicy rekrutowani i promowani są na podstawie kryteriów merytorycznych (konkursy) i ściśle sformułowanych kryteriów formalnych, a praca dla państwa jest ich jedynym źródłem dochodu. Według Webera, proces biurokratyzacji, czyli wzrostu znaczenia tego rodzaju hierarchicznych organizacji zarówno w ramach państwa, jak i wielkich przedsiębiorstw, jest nieuchronnym elementem procesu modernizacji społecznej. Nowoczesnym odpowiednikiem tego modelu w krajach o stabilnej demokracji jest apolityczna służba cywilna (civil service), do której wchodzi się na drodze konkursu i która zapewnia ciagłość działania instytucji państwowych, mimo zmiany ekip politycznych. Stosowane są różne techniki ekonomiczne i psychospołeczne, mające na celu zapewnienie wysokiego poziomu merytorycznego i moralnego aparatu biurokratycznego. Należą do nich m.in.: ustalanie płac i gratyfikacji służby cywilnej na poziomie konkurencyjnym z sektorem prywatnym, nieusuwalność ze służby, kształtowanie esprit de corps. Służba cywilna nie jest wolna od patologii (nadmierny elitaryzm, swoista alienacja społeczna), ale zapewnia stosunkowo sprawny i skuteczny system administracyjny [Crozier 1967; Bourdieu 1989; Suleiman 1974].

Polska $\mathrm{i}$ inne kraje pokomunistyczne u progu transformacji dysponowały systemami administracyjnymi, które budowane były według całkowicie odmiennych zạsad. Aparat państwowy i partia przenikały się wzajemnie. Nie było jasnych reguł prawnych. Sprawność merytoryczna i organizacyjna, zwłaszcza na wyższych szczeblach, była istotnym czynnikiem promocji, jednak podstawowe znaczenie miała lojalność polityczna. Biurokracja sama współtworzyła reguły swego działania. Po zmianie ustroju nie podjęto próby. całościowej przebudowy aparatu administracyjnego państwa, a efektywnie działająca służba cywilna nie powstała do dziś. Miały miejsce jedynie reformy i zmiany połowiczne oraz przemiany o charakterze spontanicznym. Najważniejsze $\mathrm{z}$ tych reform cząstkowych to: przebudowa struktury organów centralnych zgodnie z wymogami gospodarki rynkowej, wzmocnienie kadrowe szczególnie istotnych z punktu widzenia procesu reform gospodarczych ministerstw finansów i prywatyzacji, powołanie Krajowej Szkoły Administracji Publicznej, której absolwenci nie stworzyli jednak reformatorskiej „masy krytycznej” w ramach administracji państwowej [Kochanowicz 1999; O’Dwyer 2002].

Charakterystyczna dla polskiej biurokracji jest polityzacja sektora publicznego. Każda zmiana ekipy powoduje zdziesiątkowanie urzędniczej armii 
zwłaszcza na wyższych stanowiskach. „Przywódcy partyjni rozdają w nagrodę za wierną służbę wszelkiego rodzaju urzędy: w partiach, gazetach, towarzystwach, ubezpieczalniach, gminach i państwach. We wszelkich walkach partyjnych chodzi nie tylko o cele rzeczowe, lecz przede wszystkim o patronat nad urzędami" [Weber 1998: 66]. To spostrzeżenie Maxa Webera sprzed prawie stu lat pozostaje aktualne w dzisiejszej Polsce.

Przejawia się to w obsadzaniu stanowisk w zarządach i radach nadzorczych przedsiębiorstw państwowych i spółek $z$ udziałem Skarbu Państwa, w zarządach funduszy pozabudżetowych czy agencji rządowych. Stanowiska te są często opłacane w sposób niepozostający w żadnym związku z sukcesami i efektywnością kierowanych instytucji (vide NFZ, spółki węglowe). Tendencja ta nie tylko powoduje obejmowanie stanowisk przez ludzi niekompetentnych, ale i oznacza w praktyce przekazanie pod kontrolę partii politycznych znacznej części środków publicznych [Staniszkis 1999]. Na krótką metę jednak możliwość rozdawania posad jest korzystna dla każdej z partii, co tłumaczy niechęć poszczególnych ugrupowań do stworzenia apolitycznej służby cywilnej, gdyż zmniejszyłoby to istotnie moźliwość umacniania władzy, patronatu i ograniczyłoby dostęp do funduszy publicznych.

Ustawa z 1998 r., która powołała korpus służby cywilnej ze wszystkich pracowników i urzędników administracji rządowej, ustawiła wprawdzie wysoką poprzeczkę zarówno dla nich samych, jak i polityków i struktur państwa, ale służba ta - w jej wymiarze neutralności politycznej, profesjonalizmu i służby publicznej - nie jest poważnie traktowana przez struktury polityczne [Hausner 2004: 133].

$\mathrm{Z}$ jednej strony politycy mówią o ważnej roli, jaką spełnia apolityczna i profesjonalna służba cywilna, a $\mathrm{z}$ drugiej - dokonuje się przebudowy formalnej, a nie realnej urzędów, odwołuje się dyrektorów wyłonionych w konkursach i przez długi czas uzgadnia się warunki, jakie muszą spełnić kandydaci na wolne stanowiska. Dziś (dane z 2004 r.) w służbie cywilnej pracuje ok. 110 tys. osób, w tym tylko 1500 osób stanowią urzędnicy mianowani.

Nie ma w praktyce mowy o gwarancji długoterminowej kariery urzędniczej, szczególnie na stanowiskach najważniejszych, bo kierowniczych. Omijaniu ustawy o służbie cywilnej służy instytucja tymczasowego pełnienia obowiązków (p.o.). Dziś centralna i wojewódzka administracja jest krainą osób pełniących obowiązki. W 2001 r. jedna czwarta wszystkich stanowisk wymagających konkursu, a jest ich prawie 1700 , była obsadzona $w$ ten sposób, a więc $\mathrm{z}$ natury rzeczy tymczasowo i z politycznego nadania. Pelniącego obowiązki można zwolnić $\mathrm{z}$ dnia na dzień, co dla nowego układu politycznego może być dość wygodne. Dla państwa, dla którego urzędnicza ciągłość stanowi wartość, jest to jednak sytuacja bardzo niekorzystna. „Tymczasowi” boją się 
podejmowania decyzji na kilka miesięcy przed wyborami, a po wyborach czekaja, czy zmiecie ich kolejna rewolucja kadrowa. Sytuacja jest tym bardziej chora, że na dobrą sprawę nie tylko poszczególne osoby są w tym systemie p.o. Tak naprawdę cały korpus urzędników służby cywilnej jest ,p.o." korpusu [Paradowska 2001].

Hausner [2004] podaje przykład jednego z urzędów wojewódzkich, w którym na 25 stanowisk tylko jedno jest obsadzone w trybie konkursowym, a także ministerstwa, w którym w 2003 r. dyrektor generalny i wszyscy dyrektorzy departamentów jedynie ,pełnili" swoje obowiazki. Niestety, jest tak nadal. Przeglądając strukturę organizacyjną ministerstw ${ }^{3}$ (sierpień 2004), autorka tego opracowania znalazła w każdym $\mathrm{z}$ nich od kilkunastu do kilkudziesięciu dyrektorów i zastępców dyrektorów departamentów, którzy swoje funkcje sprawowali ,pełniąc obowiązki”. Tylko w Kancelarii Prezesa RM na 20 sekretariatów, biur i departamentów dyrektorzy „p.o." stanowili 3/4 ogółu. Sam premier natomiast triumfalnie informuje, że ,od 2 maja, gdy jego rząd został po raz pierwszy powołany, do 27 lipca obsadzono w trybie konkursu 72 wyższe stanowiska w. służbie cywilnej. To oznacza znakomite przyspieszenie, w ogóle całkowitą zmianę trendu w tym zakresie. Dotychczas na te stanowiska powoływano osoby bez konkursu, na p.o.". [PAP 2004].

Autentyczna sytuacja służby cywilnej jest taka, że w morzu ponad 110 tys. urzędników, formalnie nazywanych pracownikami korpusu służby, tkwi miniwysepka mianowanych pracowników, czyli tych już prawdziwych civil servantów, którzy mieli być oznaką nowej jakości w administracji, kadrą najwyżej wykwalifikowaną, stanowiącą to, co czasem nazywa się urzędniczą pamięcią państwa.

Badania opinii publicznej wskazują natomiast na znaczną nieufność obywateli do urzędników i administracji publicznej. Nieufne nastawienie wykazuje aż $54 \%$ badanych wobec $33 \%$ darzących zaufaniem te instytucje [CBOS 2004]. Urzędnicy i administracja publiczna usytuowani są na najniższych (obok Sejmu i Senatu, rządu, sądów oraz partii politycznych) miejscach w rankingu zaufania społecznego, co jest symptomem kryzysu legitymizacji instytucji władzy wykonawczej, sądowniczej i ustawodawczej w Polsce.

${ }^{3}$ Są to m.in. MRiRW, MZ, MENiS, MŚ, MF, MGiP, MI, MK. 


\section{Empiryczna analiza związku między biurokracją a wzrostem gospodarczym w Polsce w latach 1995-2002}

Celem badań jest ustalenie związków ilościowych między charakterystykami biurokracji a miernikami wzrostu i rozwoju gospodarczego w Polsce w latach 1995-2002. Analizę przeprowadzono przy zastosowaniu wskaźników dynamiki, wskaźników struktury, współczynników korelacji oraz analizy regresji. Zmiennymi są: poziom PKB na jednego mieszkańca, stopa wzrostu gospodarczego, zatrudnienie oraz wynagrodzenie $w$ administracji publicznej. Dane statystyczne pochodzą z GUS.

W kraju utrzymuje się dynamizm wzrostu publicznej biurokracji. Zatrudnienie w administracji publicznej, administracji obrony narodowej, obowiąkowych ubezpieczeń społecznych i powszechnych ubezpieczeniach zdrowotnych od 1995 r. do 2002 r. wzrosło o 42,5\%, a jego udział w ogólnym zatrudnieniu w gospodarce narodowej odpowiednio z 2,5 do 4,8\% (tab. 1).

Gigantyczny rozwój centrum, czyli naczelnych i centralnych organów administracji z 46 tysięcy pracowników przeciętnie w $1990 \mathrm{r}$. do 114 tysięcy w 2002 r., w warunkach transformacji ze scentralizowanej gospodarki planowej do zdecentralizowanej gospodarki rynkowej jest patologicznym fenomenem organizacyjnym. Co więcej, obserwuje się w dalszym ciągu proces zwiększania zatrudnienia. W $2000 \mathrm{r}$. było 110,8 tys. pracowników w centralnych i naczelnych organach administracji, a w 2002 r. już o $3 \%$ więcej. Z czego może wynikać ta tendencja?

Wzrostem liczby urzędników rządzi prawo Parkinsona. Northcote Parkinson zauważył, że w okresie, kiedy Imperium Brytyjskie zostało de facto zredukowane, liczba osób zatrudnionych do administrowania go zwiększyła się ponadczterokrotnie (lata 1935-1954, wzrost zatrudnienia z 372 do 1661 osób). Nie było to, oczywiście, efektem mniej efektywnej pracy urzędników; przynajmniej w pewnej części. Prawdziwy powód to tendencja pojawiająca się w administracji do robienia sobie pracy wzajemnie: jeden dla drugiego. Pracy, która w dużej części jest po prostu zbyteczna. Studia nad biurokracją doprowadziły Parkinsona do wykrycia czwartego prawa, znanego jako „prawo tysiąca", które głosi: jakakolwiek instytucja - rządowa, przemysłowa, naukowa, której zespół pracowników administracyjnych sięga tysiąca ludzi lub przekracza tę liczbę, by istnieć, nie potrzebuje żadnej innej działalności. Administracja jest samowystarczalna, żywi się własną pracą. Jest to administracja dla administracji [Parkinson 1967]. 


\section{Tabela 1}

Zatrudnienie i wynagrodzenia w administracji publicznej, obronie narodowej oraz obowiązkowych ubezpieczeniach społecznych w Polsce w latach 1995-2002

\begin{tabular}{|l|c|c|c|c|c|}
\hline \multirow{2}{*}{ Rok } & \multicolumn{2}{|l|}{ Przeciętne zatrudnienie } & \multicolumn{3}{|l|}{ Przeciętne wynagrodzenie } \\
\cline { 2 - 6 } & $\begin{array}{c}\text { osoby pełno- } \\
\text { zatrudnione }\end{array}$ & $\begin{array}{c}\text { w \% ogółu } \\
\text { zatrudnionych } \\
\text { w gospodarce }\end{array}$ & w złotych & $\begin{array}{c}\text { w \% PKB } \\
\text { per capita }\end{array}$ & $\begin{array}{c}\text { w \% przecięt- } \\
\text { nego wyna- } \\
\text { grodzenia } \\
\text { w gospodarce }\end{array}$ \\
\hline 1995 & 384600 & 2,5 & 858,77 & 10,76 & 124,29 \\
1996 & 401400 & 2,6 & 1131,22 & 11,26 & 129,39 \\
1997 & 422000 & 2,7 & 1363,02 & 11,15 & 127,89 \\
1998 & 430000 & 2,7 & 1602,55 & 11,19 & 130,00 \\
1999 & 460400 & 2,8 & 2180,08 & 13,69 & 128,46 \\
2000 & 512100 & 3,2 & 2432,44 & 13,18 & 128,45 \\
2001 & 557000 & 3,6 & 2639,36 & 13,58 & 129,06 \\
2002 & 548000 & $3,7(4,8)^{\prime 2}$ & 2717,51 & 13,47 & 129,54 \\
\hline
\end{tabular}

"w sektorze publicznym; ${ }^{2 /}$ dane za 2002 r. podano w dwóch ujęciach, tzn. $z$ uwzględnieniem pracujących $w$ gospodarstwach indywidualnych $w$ rolnictwie przy wykorzystaniu wyników: (i) Powszechnego Spisu Rolnego 1996; (ii) Narodowego Spisu Powszechnego Ludności i Mieszkań 2002 (w nawiasie).

Źródło: Opracowanie własne na podstawie Roczników Statystycznych Rzeczypospolitej Polskiej 1998, 1999, 2000, 2001, 2002.

O zachłanności administracji (biurokracji) państwowej, zwłaszcza centralnej, słyszy się od wielu lat. Jednym z jej elementów może być gratyfikacja urzędników, która swoją drogą należy do charakterystyk biurokracji weberowskiej. Czy w Polsce płace w administracji publicznej kształtują się na poziomie konkurencyjnym $\mathrm{z}$ sektorem prywatnym? Zdaniem autorki, zdecydowanie tak. Świadczy o tym fakt, że od 1995 r. przeciętne wynagrodzenie w administracji publicznej, obronie narodowej, obowiązkowych ubezpieczeń społecznych i powszechnych ubezpieczeniach zdrowotnych $w$ relacji do PKB na jednego mieszkańca wzrosły $\mathrm{z} 10,8$ do $13,5 \%$, natomiast $\mathrm{w}$ stosunku do przeciętnego wynagrodzenia brutto w gospodarce odpowiednio ze 124,3 do 129,5\% (tab. 1). Podczas gdy PKB na osobę $\mathrm{w}$ ujęciu realnym $\mathrm{w}$ badanym okresie wzrósł o $29 \%$, przeciętne wynagrodzenie w administracji zwiększyło się aż o $62 \%$ (dla porównania przeciętne wynagrodzenie w gospodarce o $55 \%$ ).

Ważny jest także rozkład pełnozatrudnionych według wysokości wynagrodzenia. Według obliczeń własnych opartych na danych statystyki masowej, w październiku 2002 r. 53\% pełnozatrudnionych w administracji publicznej, obronie narodowej, obowiązkowych ubezpieczeniach społecznych oraz powszechnych ubezpieczeniach zdrowotnych otrzymywało wynagrodzenie wyższe od przeciętnego w gospodarce. Biorąc pod uwagę ogół pełnozatrudnionych, 
wskaźnik ten wynosił $35 \%$. O ile w całej gospodarce $8,4 \%$ pełnozatrudnionych uzyskiwało wynagrodzenie najniższe, równe bądź niższe od $40 \%$ średniej krajowej, to w administracji odsetek ten wynosił tylko $1 \%$. W najwyższym przedziale wynagrodzenia (280\% średniej krajowej lub więcej) znajdowało się 2,5\% ogółu pełnozatrudnionych, a 3,4\% pełnozatrudnionych w administracji.

Badania z wykorzystaniem szeregu czasowego wykazały, że istnieje wysoka ujemna korelacja (współczynnik Pearsona $=-0,95$ ) między stopą wzrostu gospodarczego a poziomem zatrudnienia $\mathrm{w}$ administracji publicznej, obronie narodowej, obowiązkowych ubezpieczeniach społecznych oraz powszechnych ubezpieczeniach zdrowotnych w Polsce. Dodatnią wyraźną współzależność $(0,94)$ wykazano między tym zatrudnieniem a PKB na jednego mieszkańca.

Przeciętne wynagrodzenia realne $w$ sektorze także były wysoko ujemnie skorelowane ze stopa wzrostu gospodarczego $(-0,9)$, natomiast dodatnio z poziomem realnego PKB per capita $(0,96)$.

Wpływ zatrudnienia i wynagrodzeń w administracji publicznej na stope wzrostu gospodarczego oraz poziom PKB na jednego mieszkańca ukazano za pomocą rachunku regresji prostej (z jedną zmienną niezależna) ${ }^{4}$. Modele liniowe przyjęto na podstawie analizy graficznej. Wyniki przedstawia tabela 2.

Hipoteza o braku wpływu zatrudnienia w administracji publicznej, obronie narodowej, obowiązkowych ubezpieczeniach społecznych oraz powszechnych ubezpieczeniach zdrowotnych zarówno na stopę wzrostu gospodarczego, jak i poziom PKB na jednego mieszkańca jest wysoce niewiarygodna. Wyniki estymacji wskazują na statystycznie istotny ujemny wpływ zatrudnienia $\mathrm{w}$ administracji (zarówno w ujęciu absolutnym, jak też jako odsetek ogólnego zatrudnienia.w gospodarce) na stopę wzrostu gospodarczego. Podobnie ujemny, statystycznie istotny wpływ na dynamike wzrostu gospodarki ma poziom wynagrodzeń realnych $w$ administracji. Nie stwierdzono natomiast statystycznie istotnego związku między stopą wzrostu gospodarczego a wskaźnikiem relacji płac $\mathrm{w}$ administracji do płac przeciętnych $\mathrm{w}$ całej gospodarce narodowej.

W przypadku stopy wzrostu gospodarczego modele wykazały, że $89 \%$ zaobserwowanego $w$ próbie zróżnicowania jej poziomu zostało wyjaśnione jej regresją liniową względem wielkości zatrudnienia w administracji; w $77 \%$ natomiast poziomem realnego wynagrodzenia w administracji. Zmienność. PKB per capita $\mathrm{w} 86 \%$ można wyjaśnić zmiennością zatrudnienia $\mathrm{w}$ administracji oraz w $91 \%$ zmiennościąjej przeciętnego wynagrodzenia realnego.

\footnotetext{
${ }^{4} \mathrm{~W}$ analizie regresji przyjęto warunek ceteris paribus, czyli analizuje się wpływ jednej zmiennej na zmienną zależna, pomijając zmiany innych czynników, które jednocześnie mogłyby wpłynąć na jej poziom. Autorka ma świadomość, że w naukach społecznych metoda ta jest przybliżeniem większości związków.
} 


\section{Tabela 2}

Zależność stopy wzrostu gospodarczego oraz PKB per capita od zmiennych ilościowych charakteryzujących biurokrację w Polsce w latach 1995-2002 (wyniki regresji liniowych)

\begin{tabular}{|l|c|c|c|c|c|}
\hline Wyniki estymacji modelu & $\mathrm{y}_{1}=\mathrm{f}\left(\mathrm{x}_{1}\right)$ & $\mathrm{y}_{1}=\mathrm{f}\left(\mathrm{x}_{2}\right)$ & $\mathrm{y}_{1}=\mathrm{f}\left(\mathrm{x}_{3}\right)$ & $\mathrm{y}_{2}=\mathrm{f}\left(\mathrm{x}_{1}\right)$ & $\mathrm{y}_{2}=\mathrm{f}\left(\mathrm{x}_{2}\right)$ \\
\hline $\begin{array}{l}\text { Współczynnik } \\
\text { determinacji AR }\end{array}$ & 0,89 & 0,77 & 0,86 & 0,86 & 0,91 \\
\hline Stała równania (a) & 19,4 & 15,13 & 18,02 & 3664 & 4931 \\
\hline [Błąd standardowy stałej] & 2,03 & 2,19 & 2,05 & 852,7 & 513,9 \\
\hline Statystyka t-Studenta & 9,57 & 6,91 & 8,78 & 4,30 & 9,6 \\
\hline Wartość p & 0,0 & 0,0 & 0,0 & 0,01 & 0,0 \\
\hline Współczynnik regresji (b) & $-0,032$ & $-0,009$ & $-4,58$ & 12,2 & 3,81 \\
\hline [Błąd standardowy b] & 0,004 & 0,0019 & 0,68 & 1,82 & 0,44 \\
\hline Statystyka t-Studenta & $-7,47$ & $-4,98$ & $-6,71$ & 6,72 & 8,72 \\
\hline Wartość p p & 0,0 & 0,002 & 0,0 & 0,0 & 0,0 \\
\hline Wartość statystyki F & 55,8 & 24,8 & 45,07 & 45,15 & 76,02 \\
\hline
\end{tabular}

"krytyczne-poziomy istotności

Objaśnienia zmiennych: $y_{1}$ - stopa wzrostu gospodarczego wyrażona procentowo; $y_{2}-$ realny PKB per capita (zf) w cenach z 1995 r.; $x_{1}$ - liczba pelnozatrudnionych $w$ administracji publicznej, obronie narodowej, obowiąkowych ubezpieczeniach społecznych i powszechnych ubezpieczeniach zdrowotnych (tys. osób); $x_{2}$ - przeciętne wynagrodzenie w administracji publicznej, obronie narodowej, obowiąkowych ubezpieczeniach społecznych i powszechnych ubezpieczeniach zdrowotnych ( $w$ zf) $w$ ujęciu realnym; $x_{3}$ - udział zatrudnionych $w$ administracji publicznej, obronie narodowej, obowiązkowych ubezpieczeniach społecznych i powszechnych ubezpieczeniach zdrowotnych w ogólnym zatrudnieniu w gospodarce narodowej.

Źródło: Badania własne.

Z funkcji wynika, że istnieje dodatni, statystycznie istotny związek między poziomem PKB w przeliczeniu na jednego mieszkańca a zatrudnieniem, jak też wynagrodzeniem realnym $\mathrm{w}$ administracji publicznej, obronie narodowej, obowiazkowych ubezpieczeniach społecznych i powszechnych ubezpieczeniach zdrowotnych. Przyrost pełnozatrudnionych w administracji o 1 tys. spowodował wzrost realnego PKB per capita o 12 zł. Z kolei zmiana wynagrodzeń realnych o 1 zł spowodowała wzrost PKB per capita o 3,8 zł. Zwiazek przyczynowo-skutkowy nie jest tu jednak oczywisty. Z ekonomicznego punktu widzenia bardziej prawdopodobny wydaje się wpływ PKB na poziom wynagrodzeń, a nie odwrotnie.

\section{Podsumowanie i wnioski końcowe}

Sa dwa sposoby organizacji działania ludzi w ramach społeczeństwa, jednym jest zarządzanie biurokratyczne, drugim jest zarządzanie nastawione na zysk. Istnieją obszary działalności człowieka, w których wybór pomiędzy nimi 
nie podlega kwestii i w których biurokracja musi dominować. Należą do nich podstawowe usługi państwa. Efektywności urzędów nie da się sprawdzić rachunkiem zysków i strat, ponieważ nie ma żadnej metody, która za pomocą procedur rachunkowych mogłaby wykazać osiąnnięcie sukcesu czy poniesienie porażki.

Niniejsze opracowanie generalnie nie odnosi się do postępowania urzędników w administracji publicznej, lecz biurokracji jako systemu organizacji społecznej i jej związku ze wzrostem gospodarczym kraju. Przegląd literatury wykazał, że biurokracja $\mathrm{w}$ tym aspekcie nie jest jednoznacznie postrzegana. W życiu codziennym powszechnie przypisuje się jej winę za hamowanie swobodnej działalności gospodarczej. Według cytowanego wcześniej Parkinsona, „biurokracja to dobrze zorganizowana zaraza”.

Czy więc istnieje lekarstwo na biurokrację? Pytanie to zadał sobie m.in. Mises, od razu odpowiadając, że jest nim tylko rozsądek i wiedza. Wiedza zgromadzona przez naukowców wskazuje natomiast, że sprawnie zorganizowana biurokracja typu weberowskiego przyczyniła się w wielu krajach do wzrostu dynamiki gospodarki narodowej.

Analiza empiryczna dla Polski, przeprowadzona na podstawie szeregu czasowego obejmującego okres 1995-2002, dowiodła, że istnieje ścisła ujemna korelacja między zatrudnieniem w administracji publicznej, obronie narodowej, obowiązkowych ubezpieczeniach społecznych oraz powszechnych ubezpieczeniach zdrowotnych a stopą wzrostu gospodarczego kraju, jak też między przeciętnym wynagrodzeniem realnym $w$ tym sektorze a stopą wzrostu gospodarczego.

Analiza regresji liniowej wykazała, że:

- liczba osób (tys.) pełnozatrudnionych w administracji publicznej $\left(\mathrm{x}_{1}\right)$ ma statystycznie istotny ujemny wpływ na stopę wzrostu gospodarczego $\left(\mathrm{y}_{1}\right)$ : $\mathrm{y}_{1}=19,4-0,032 \mathrm{x}_{1}$

- przeciętne realne wynagrodzenie w administracji publicznej $\left(\mathrm{x}_{2}\right)$ ma statystycznie istotny ujemny wpływ na stope wzrostu gospodarczego $\left(\mathrm{y}_{1}\right)$ : $\mathrm{y}_{1}=15,13-0,009 \mathrm{x}_{2}$

- liczba osób (tys.) pełnozatrudnionych w administracji publicznej $\left(\mathrm{x}_{1}\right)$ ma statystycznie istotny dodatni wplyw na realny $\mathrm{PKB}$ per capita $\left(\mathrm{y}_{2}\right)$ : $\mathrm{y}_{2}=3664+12,2 \mathrm{x}_{1}$

- przeciętne realne wynagrodzenie w administracji publicznej $\left(\mathrm{x}_{2}\right)$ ma statystycznie istotny dodatni wplyw na realny PKB per capita $\left(\mathrm{y}_{2}\right)$ : $\mathrm{y}_{2}=4931+3,81 \mathrm{x}_{2}$.

Nie stwierdzono natomiast statystycznie istotnego związku między relacją przeciętnego wynagrodzenia $\mathrm{w}$ administracji publicznej do przeciętnego wynagrodzenia w gospodarce narodowej ani ze stopa wzrostu gospodarczego, ani $\mathrm{z}$ poziomem $\mathrm{PKB}$ w przeliczeniu na jednego mieszkańca. 


\section{Literatura}

AMSDEN A. (1989): Asia's Next Giant: South Korea and Late Industrialization. Oxford University Press, New York.

BATES R.H. (1981): Markets and States in Tropical Africa: The Political Basis of Agricultural Policies, University of California Press, Berkeley, CA.

BOURDIEAU P. (1989): La noblesse d'Etat, Editions de Minuit, Paris.

BUCHANAN J.M., TOLLISON R.D., TULLOCK G. (1980): Toward a Theory of the Rent-Seeking Society. College Station, Texas A\&M University Press, Texas.

CBOS (2004): Zaufanie w sferze publicznej i prywatnej. Komunikat z badań BS/39/2004 .

COLCLOUGH C., MANOR J. (1991): States or Markets: Neo-liberalism and the Development Policy Debate. Clarendon Press, Oxford.

COLLANDER D. (1984): Neoclassical Political Economy: an Analysis of Rent-Seeking and DUP Activities., MA: Ballinger, Cambridge.

CROZIER M. (1967): Biurokracja. Anatomia zjawiska, PWE Warszawa.

DELACROIX J., RAGIN CH. (1981): Structural blockage: a cross-national study of economic dependency, state efficacy, and underdevelopment, American Journal of Sociology No 86:1311-1347.

EVANS P. (1995): Embedded Autonomy: States and Industrial Transformation, Princeton University Press, Princeton, NJ.

HAUSNER W. (2004): Korpus służby cywilnej - uwarunkowania społeczne i polityczne. Slużba Cywilna $\mathrm{Nr}$ 8:133-142.

JOHNSON Ch. (1982): MITI and the Japanese Miracle: the Growth of Industrial Policy, 1925-1975, Stanford University Press, Stanford.

KLITGAARD R. (1988): Controlling Corruption, University of California Press, Berkeley, CA.

KNACK S., KEEFER P. (1995): Institutions and Economic Performance: Cross-country tests using Alternative Institutional Measures, Economics and Politics No 7(3), [November]: 207-227.

KOCHANOWICZ J. (1999): Ekonomia polityczna konsolidacji reform. [W:] Raporty CASE Nr 29, http://www.case.com.pl/upload/publikacja_plik/rc29part1.pdf, s. 19.

KOPALIŃSKI W. (1968): Słownik wyrazów obcych i zwrotów obcojęzycznych, wyd. Wiedza Powszechna, Warszawa: 106.

KRUEGER A.O. (1974): The Political Economy of the Rent-Seeking Society, American Economic Review No 64, 3 (June): 291-303.

KYDLAND F.E., PRESCOTT-E.C. (1977): Rules Rather than Discretion: the Inconsistency of Optimal Plans, Journal of Political Economy vol. 85, No 3:473-491.

LUCAS R.E. Jr. (1988): On the Mechanics of Economic Development, Journal of Monetary Economics No 22 (1): 3-42.

MAURO P. (1995): Corruption and Growth, Quarterly Journal of Economics No 110 (August): 681-712.

MISES V.L. (1998): Biurokracja, Wyd. Instytut Liberalno-Konserwatywny, Lublin.

NORDHAUS W.D. (1975): The Political Business Cycle, Review of Economic Studies No 42: 169-90. 
Nowa encyklopedia powszechna PWN, Wydawnictwo Naukowe PWN SA, http://encyklopedia.pwn.pl/8170_1.html

O'DWYER C. (2002): Civilizing the State Bureaucracy: The Unfulfilled Promise of Public Administration Reform in Poland, Slovakia, and the Czech Republic (1990-2000), (May 1, 2002). Berkeley Program in Soviet and Post-Soviet Studies. Paper 2002_01odwy. http://repositories.cdlib.org/iseees/bps/2002_01-odwy

PAP (2004): Belka o realizacji programu rządu, PAP, jkl /2004-08-03.

PARADOWSKA J. (2001): Pełniący obowiązki. Służba cywilna w stanie nieczynnym, Polityka Nr 22 (2300).

PARKINSON N.C. (1967): Prawo zwłoki, (rozdział 12: Czwarte prawo Parkinsona), Wyd. Książka i Wiedza, Warszawa.

RAUCH J., EVANS P. (1999): Bureaucracy and Growth: A Cross-National Analysis of the Effects of 'Weberian' State Structures on Economic Growth, http://sociology. berkeley.edu/faculty/evans/burperf.html

ROMER P. (1990): Endogenous Technological Change, Journal of Political Economy No 94: $71-102$.

ROMER P. (1994): The Origins of Endogenous Growth, Journal of Economic Perspectives. 8(1): 3-22.

ROSE-ACKERMAN R. (2001): Korupcja i rządy, Wyd. Sic!, Warszawa.

SNYDER D., KICK E. (1979): Structural Position in the World System and Economic Growth, 1955-1970: A Multiple-Network Analysis of Transnational Interactions, American Journal of Sociology 84: 1096-1126.

STANISZKIS J. (1999): Czy straciliśmy 10 lat wolności [rozmowa z Jadwigą Staniszkis], Nasz Dziennik, 11-12 września.

STEPAN A. (1978): The State and Society. Peru in comparative perspective, Princeton University Press, Princeton.

STIGLITZ J.E (1998): Distinguished Lecture on Economics in Government: The Private Uses of Public Interests: Incentives and Institutions, Journal of Economic Perspectives, Spring 12(2): 3-22.

STIGLITZ J.E. (1991): The Economic Role of the State: Efficiency and Effectiveness, [W:] T.P. Hardiman and M. Mulreany, eds.: Efficiency and Effectiveness in the Public Domain, The Economic Role of the State. Institute of Public Administration, Dublin: 37-59.

STIGLITZ J.E. (1997): The Role of Government in Economic Development, [W:] M. Bruno and B. Pleskovic, eds., Annual World Bank Conference on Development Economics 1996, The World Bank: 11-23.

SULEIMAN E.N. (1974): Politics, Power and Bureaucracy in France. The Administrative Elite, Princeton University Press, Princeton, NJ.

WADE R. (1990): Governing the Market: Economic Theory and the Role of Government in Taiwan's Industrialization, Princeton University Press, Princeton, NJ.

WATERBURY J. (1983): The Egypt of Nasser and Sadat, Princeton University Press, Princeton.

WEBER M. (1978): Economy and Society. Edited by Guenter Roth and Claus Wittich, Bedminster Press, New York.

WEBER M. (1998): Polityka jako zawód i powołanie, Wyd. Znak Kraków; Fundacja im. Stefana Batorego, Warszawa. 
World Bank (1993): The East Asian Miracle: Economic Growth and Public Policy (A World Bank Policy Research Report), Oxford University Press, New York.

World Bank (1997): World Development Report 1997. The State in a Changing World, IBRD Washington, D.C.

\section{Bureaucracy and Country's Economic Growth}

\section{Abstract}

The objective of this paper is to show that the type of state bureaucracy is a key determinant of the country's economic growth. In its theoretical part, the paper reviews the scientific literature that addresses the impact of the state organisation and quality of governance on economic growth and development. In the second part, the author empirically examines a quantitative relationship between macroeconomic performance in Poland over the 1995-2002 period and such bureaucracy characteristics as employment in public administration, defence and compulsory social security as well as the average remunerations in this section.

The findings indicate that the country's economic growth rate and its GDP per capita are directly correlated to the level of employment and wages in public administration sector. According to simple lineral regression analysis, both an increase in the number of public bureaucrats and the level of their wages adversely affect the rate of economic growth. 